\title{
Evaluation of Some Reproductive and Developmental \\ Parameters of Paracoccus Marginatus (Hemiptera: Pseudococcidae) Under Laboratory Conditions
}

\author{
Yawavi Eyram Gnomou \\ Applied Entomology Laboratory, Faculty of Sciences, University of Lome \\ 01 B. P. 1515 , Lome 1 Togo \\ Tel: +22899695668Ｅ-mail: yawavi.gnomou@gmail.com
}

Seth Wolali Nyamador (Corresponding author)

Applied Entomology Laboratory, Faculty of Sciences, University of Lome

01 B. P. 1515 , Lome 1 Togo

Tel: +228 90115504/+22897235518Ｅ-mail: seth.nyamador@gmail.com

\author{
Komina Amevoin \\ Applied Entomology Laboratory, Faculty of Sciences, University of Lome \\ 01 B. P. 1515, Lome 1 Togo \\ Tel: +22890187320Ｅ-mail: kamevoin@gmail.com
}

\section{Obinna Ajuonu}

International Institute of Tropical Agriculture, IITA-Benin

08 BP 0932, Cotonou, Benin

E-mail: o.ajuonu@cgiar.org

\section{Georg Goergen}

International Institute of Tropical Agriculture, IITA-Benin

08 BP 0932, Cotonou, Benin

E-mail: g.goergen@cgiar.org 
Isabelle Adolé Glitho

Applied Entomology Laboratory, Faculty of Sciences, University of Lome

01 B. P. 1515, Lome 1 Togo

Tel: +22890102059Ｅ-mail: iglitho@yahoo.fr

Received: May 26, 2020

doi:10.5296/jas.v8i3.17523
Accepted: August 10, 2020

Published: August 13, 2020

URL: https://doi.org/10.5296/jas.v8i3.17523

\begin{abstract}
The papaya mealybug Paracoccus marginatus Williams and Granara De Willink (Hemiptera: Pseudococcidae) is an invasive insect species attacking a diverse range of host plants. It causes an enormous damage to crops including those of very great economic importance including the papaya, being its main host. Considering its potential threat to fruit and crops of economic importance throughout Togo, this study, which was carried out in the laboratory under conditions of $28 \pm 2{ }^{\circ} \mathrm{C}, 75 \pm 5 \% \mathrm{RH}, 12: 12 \mathrm{LD}$, made it possible to determine some biological parameters of $P$. marginatus, essential for the implementation of management programmes for this species. The results showed that a female of $P$. marginatus had three periods of reproductive activity, namely pre-oviposition, oviposition and post-oviposition periods which last on average $7.74 \pm 1.26 ; 6.13 \pm 3.02$ and $7.45 \pm 4.27$ days respectively. During oviposition, a female $P$. marginatus lays an average of $25.262 \pm 11.16$ eggs per day, for an average total of $224.32 \pm 29.99$ eggs during her lifetime, which averages $18.44 \pm 3.31$ days. During the post-embryonic development of $P$. marginatus which lasts on average 25.98 \pm 4.47 days for the female against $29.70 \pm 5.58$ days for the male and which passes through three larval stages, the important mortality rates of the first and second larval stages were noted. They are estimated to an average of $61.40 \pm 0.05$ and $52.8 \pm 0.025$ respectively. However, at the third stage, the rate is $35.02 \pm 0.03$ for the female and zero for the male. These results provide a better understanding of the biology of $P$. marginatus under local conditions and thus provide a basis for controlling the population of the species and the damage it causes in Togo.
\end{abstract}

Keywords: daily egg laying, mortality rate, papaya mealybug, Paracoccus marginatus, Togo

\title{
1. Introduction
}

The papaya mealybug, Paracoccus marginatus Williams \& Granara from Willink 1992 (Hemiptera: Pseudococcidae) is a soft-bodied polyphagous that suck insect native to Mexico and Central America where it is not a major pest because it is controlled by natural enemies (Walker et al., 2006 ; Miller et al., 1999). In the early 1990s, P. marginatus became an invasive species and it was found itself outside its native range. It was recorded in the Caribbean islands in 1995, where its population spread rapidly and is considered a pest of 
papaya (Miller et al., 1999). In 1998, P. marginatus was first time recorded on hibiscus in Florida in Palm Beach and subsequently spread to several other countries such as Guam in 2002 (Meyerdirk et al., 2004), the Republic of Palau in 2003 (Muniappan et al., 2006) and Hawaii in 2006 (Heu et al., 2007). In the early 2008, it spread to South-East Asia, where it was discovered in the Western provincial districts of Colombo and Gampaha in Sri Lanka, in south India, Indonesia, Malaysia and Thailand infecting a large number of plant species (Galanihe et al., 2011; Saengyot and Burikam, 2011). P. marginatus had spread to the Indian subcontinent before reaching the African continent. In the late 2009, P. marginatus was first discovered on the African continent in the Accra region of Ghana, where it was reported from the Nsawam orchards in the Eastern region and Bawjiase in the central region, about $30 \mathrm{~km}$ north and $60 \mathrm{~km}$ east of Accra, respectively (Cham et al., 2011). In the early 2010, it was observed in Benin mainly on cassava and jatropha (Goergen et al., 2011). The pest then spread along the West African coast and invaded Togo, Nigeria, Cameroon and recently Gabon (Goergen et al., 2014). It was also found in Senegal in 2013 and Seychelles in 2014 (Muniappan, 2014). According to the work of Helemul (2013), P. marginatus caused enormous damage to the papaya Carica papaya $\mathrm{L}$ in many countries in the world more than its other host plants.

P. marginatus damage on papaya includes sap suction after insertion of its stylet into the conductive vessels of the plant (Sharma et al., 2013). Thus, heavy infestation of the pest leads to leaf yellowing, wilting and falling; bud deformation and early fruit drop (Tanwar et al., 2010; Suganthy et al., 2012; Kirsur et al., 2014; Ben-Dov, 2015). Also P. marginatus excretes from honeydew which favours the development of moulds, fumagine hindering photosynthesis of essential parts of the plant (leaf, stem and fruit) (Muniappan, 2011). This causes chlorosis of leaves and the development of thick white wax on fruits that become inedible (Muniappan, 2011).

P. marginatus shows significant sexual dimorphism (Goergen et al., 2011). Adult yellow and apteran females are approximately $2.2 \mathrm{~mm}$ long and $1.4 \mathrm{~mm}$ wide with a segmented flat oval body and well developed legs (Miller et al., 1999). They are covered with a waxy secretion bordered by white filaments and cottony in appearance (Miller et al., 1999; Walker et al., 2003). In contrast, winged and pink males are about $1.0 \mathrm{~mm}$ long with an elongated oval body; they have no mouth parts and therefore do not cause damage (Miller et al., 1999; Walker et al., 2003). According to Miller et al. (1999), P. marginatus reproduces sexually. The eggs are laid in an ovisac under or in the extension of the female. There are four developmental stages in females versus five in males where the last larval stage (fourth instar) is completed in the internal side of cocoon such as a pupa (Miller et al., 1999). P. marginatus has a high rate of development, survival and enormous reproductive capacity allowing its population to reach a very high rate in a short time. An average female lays 100-600 eggs in an ovisac over a period of one to two weeks (Walker et al., 2011). Adult females have an average longevity of $19.6 \pm 0.18$ days and $39.2 \pm 1.12$ days of total development time under conditions of $25 \pm 2{ }^{\circ} \mathrm{C}$ temperature and $60 \pm 5 \% \mathrm{RH}$, with a photoperiod of 12:12 (L:D) (Munwar et al., 2016). Under these same conditions, adult males have a development time of $24.6 \pm 1.03$ days and an average longevity of $2.5 \pm 0.5$ days (Munwar et al., 2016). 
The recent invasion of the papaya mealybug in Togo has caused damage to papaya and other economically important crops. Therefore, it has become essential to understand the biology of this pest under the local environment. For this purpose, this study was implemented in order to have data on the biology of $P$. marginatus in the laboratory under biotic conditions similar to those prevailing in southern Togo in order to better control it. Specifically, the duration of development and mortality rate of the different stages of development of $P$. marginatus and the daily fertility and pre-oviposition, oviposition and post-oviposition durations of a female of this species were determined.

\section{Materials and Methods}

\subsection{Study Sites}

This study was conducted in the Biodiversity Centre (or Biodiversity Museum) with an area of approximately $200 \mathrm{~m}^{2}$. This centre is an integral entity of the International Institute of Tropical Agriculture in the commune of Abomey-Calavi, Benin (IITA-Benin), where colonies of A. papayae are mass produced in the laboratory.

\subsection{Production of Host Plant for Experiments}

A nursery was planted with papaya seeds ( $C$. papaya L.). Two weeks after the first seedlings have emerged, they are transplanted into plastic pots at a rate of three feet per pot. Two weeks after this transplanting, the seedlings are pruned to obtain sturdy stems. The seedlings are watered as needed with drinking water.

After the regrowth of new stems and leaves, pots containing seedlings with sturdy stems are selected. These stems are then washed and placed in the breeding cages in the laboratory.

\subsection{Pest Breeding: Paracoccus Marginatus}

Individuals of the papaya mealybug, $P$. marginatus, were initially collected from papaya plants (C. papaya L) located within the IITA-Benin station. The ovisacs were collected and put into transparent jars covered with very fine mesh netting. The breeding was carried out in a breeding room under temperature of $28 \pm 2{ }^{\circ} \mathrm{C}, 75 \pm 5 \% \mathrm{RH}$ (Relative Humidity) and a photoperiod of 12:12 (L:D). The ovisac jar was then placed in a breeding cage measuring 58 $\times 50 \times 45,5 \mathrm{~cm}$ covered laterally with very fine mesh nets, from the top with plexiglass glass and at the bottom with plywood and longitudinally surmounted by light bulbs held by iron bars containing pots of previously cultivated papaya plants. When the eggs hatch, the neonate larvae can pass over the papaya plants in the cages.

\subsection{Study of Reproductive Activity and Survival of Females of P. Marginatus}

In ten breeding cages, each containing three pots of papaya, $P$. marginatus ovisacs were introduced in order to permanently have individuals of different stages of the pest for different experiments.

To assess the daily egg laying potential of an adult female $P$. marginatus, a 24-hour egg ovisacs were collected from the reserve colony (where pre-oviposition females are selected and marked with the indelible marker). These eggs were transferred to three healthy papaya 
plants potted in another cage and followed until hatching. As soon as the eggs hatched, the neonate larvae were observed daily until the adult females appeared and were marked with an indelible marker. In each pot, the number of female individuals was then reduced to 10 unevenly on the three plants according to their size (large plants carried 4 individuals and small plants, 2 individuals) by removing the excess. These 10 females were monitored daily before, during and after the laying period. The eggs laid by each female were collected daily (using the small brush and hand magnifier) and counted using a hand tally counter with a binocular magnifier using a punch needle to open the ovisac.

This procedure was repeated daily until the last egg laying of these females; their pre-oviposition, oviposition and post-oviposition times were recorded. The female was considered dead when no reaction was observed after contact with the hair of the small brush.

This experiment was replicated 5 times, corresponding to a total follow-up of 50 females.

The number of days between emergence of the females and laying of the first eggs, referred to the pre-oviposition period, was noted in each female. Knowing the duration of this period in all monitored females, the average pre-oviposition duration was determined.

Then the period during which a female lays eggs (oviposition period) was recorded and the average was calculated from the oviposition time of all females monitored. The number of days between the laying of the last eggs and the death of the females, constituting the post-oviposition period of each female, was noted. Knowing this duration in all females, the average post-oviposition duration was determined as well as the average post-oviposition age.

The mortality rate $(\mathrm{Rm})$ of each stage of development of $P$. marginatus was then evaluated by collecting and counting exuvia from all stages until the appearance of adult females in the pre-oviposition period. This rate $(\mathrm{Rm})$ was calculated from this formula:

$$
\mathrm{R}=\frac{\mathrm{N}_{1}-\mathrm{N}_{2}}{\mathrm{~N}_{1}} \times 100
$$

With $\mathrm{N}_{1}$ : Total number of individuals of the stage of development considered of $P$. marginatus,

$\mathrm{N}_{2}$ : Total number of individuals in the next stage of development of $P$. marginatus.

\subsection{Statistical Analysis}

XLSTAT 2008.6.03 software was used to analyze the different results from the experiments. Comparisons of the means were made by analysis of variance (ANOVA) followed by the SNK (Student Newman Keul) test at the 5\% threshold.

\section{Results}

\subsection{Determination of Some Biological Parameters of P. Marginatus}

\subsubsection{Development Time of P. Marginatus on Papaya}

The average development time varies according to the stage and sex of the insect. It shall be 
$10.71 \pm 2.49$ days for eggs and $5.71 \pm 0.75$ days for $L_{1}$. For $L_{2}$, it is $7.28 \pm 0.75$ days for females and $7.14 \pm 0.37$ days for males. For $\mathrm{L}_{3}$, it is $2.28 \pm 0.48$ days for females and $3.00 \pm$ 0.53 days for males. The mean total development time of the male scale is relatively longer $(29.70 \pm 5.58$ days) than that of the female $(25.98 \pm 4.47$ days) (Table 1$)$.

\subsubsection{Mortality Rates of the Different Pre-imaginal Stages of P. Marginatus}

Mortality rates for stages $\mathrm{L}_{1}$ and $\mathrm{L}_{2}$ are higher than for stages $\mathrm{L}_{3}$ and $\mathrm{L}_{4}$. The highest $\mathrm{L}_{1}$ mortality $(61.40 \%)$ was offset by low $\mathrm{L}_{3}$ female mortality. There was no mortality in $\mathrm{L}_{3}$ and L4 stage males (Table 2).

Table 1. Average development time of different stages of $P$. marginatus reared on papaya $(n=25)$

\begin{tabular}{|c|c|c|c|c|c|c|c|c|}
\hline \multicolumn{7}{|c|}{ Duration of development stages } & \multirow{2}{*}{\multicolumn{2}{|c|}{$\begin{array}{l}\text { Total average } \\
\text { duration }\end{array}$}} \\
\hline \multirow[t]{2}{*}{ Eggs } & \multirow[t]{2}{*}{$\mathrm{L}_{1}$} & \multicolumn{2}{|c|}{$\mathrm{L}_{2}$} & \multicolumn{2}{|c|}{$\mathrm{L}_{3}$} & \multirow{2}{*}{$\frac{\mathrm{L} 4}{\text { Male }}$} & & \\
\hline & & Female & Male & Female & Male & & Female & Male \\
\hline $\begin{array}{c}10.71 \pm \\
2.49\end{array}$ & $\begin{array}{c}5.71 \pm \\
0.75\end{array}$ & $\begin{array}{l}7.28 \pm \\
0.75\end{array}$ & $\begin{array}{c}7.14 \pm \\
0.37\end{array}$ & $\begin{array}{c}2.28 \pm \\
0.48\end{array}$ & $\begin{array}{c}3.00 \pm \\
0.53\end{array}$ & $\begin{array}{c}3.14 \pm \\
0.69\end{array}$ & $\begin{array}{c}25.98 \pm \\
4.47\end{array}$ & $\begin{array}{r}29.70 \\
\pm 5.58\end{array}$ \\
\hline- & - & \multicolumn{2}{|c|}{$\begin{array}{c}F=27.8 \\
P=0.006\end{array}$} & \multicolumn{2}{|c|}{$\begin{array}{c}F=2.64 \\
P=0.086\end{array}$} & - & \multicolumn{2}{|c|}{$\begin{array}{l}F=7.2 \\
P=0.043\end{array}$} \\
\hline
\end{tabular}

Table 2. Mortality rate (\%) of each larval stage of $P$. marginatus $(\mathrm{n}=25)$

\begin{tabular}{ccccc}
\hline \multicolumn{4}{c}{ Mortality rates (\%) at different stages } \\
\hline $\mathrm{L}_{1}$ & $\mathrm{~L}_{2}$ & \multicolumn{2}{c}{$\mathrm{L}_{3}$} & $\mathrm{~L}_{4}$ \\
\cline { 3 - 4 } & & Female & Male \\
$61.40 \pm 0.05$ & $52.8 \pm 0.025$ & $35.02 \pm 0.03$ & 0 & 0 \\
\hline
\end{tabular}

\subsubsection{Periods of Reproductive Activity and Daily Fertility of a Female P. Marginatus}

The different periods of $P$. marginatus reproductive activity, i.e. pre-oviposition, oviposition and post-oviposition periods are on average long $7.74 \pm 1.26 ; 6.13 \pm 3.02$ and $7.45 \pm 4.27$ days respectively (Table 3 ). The oviposition period is from the 7 th to the 24 th day after the emergence of females. The number of eggs laid by females of $P$. marginatus fluctuated with their age. Females laid a maximum number of eggs (23 to 38) between the 8th and 11th day after emergence. Peak egg-laying is obtained on the 10th day of emergence as can be seen in the Figure 1.

The average fertility of a female $P$. marginatus is $224.32 \pm 29.99$ eggs during her lifetime with a daily egg laying of $25.262 \pm 11.16$ eggs. 


\section{Macrothink}

Journal of Agricultural Studies

ISSN 2166-0379

2020, Vol. 8, No. 3

Table 3. Average duration of different periods of reproductive activity of $P$. marginatus females $(\mathrm{n}=50)$

Periods of reproductive activity

Pre-oviposition

Oviposition

Post-oviposition
Average Duration (Days)

$7.74 \pm 1.26$

$6.13 \pm 3.02$

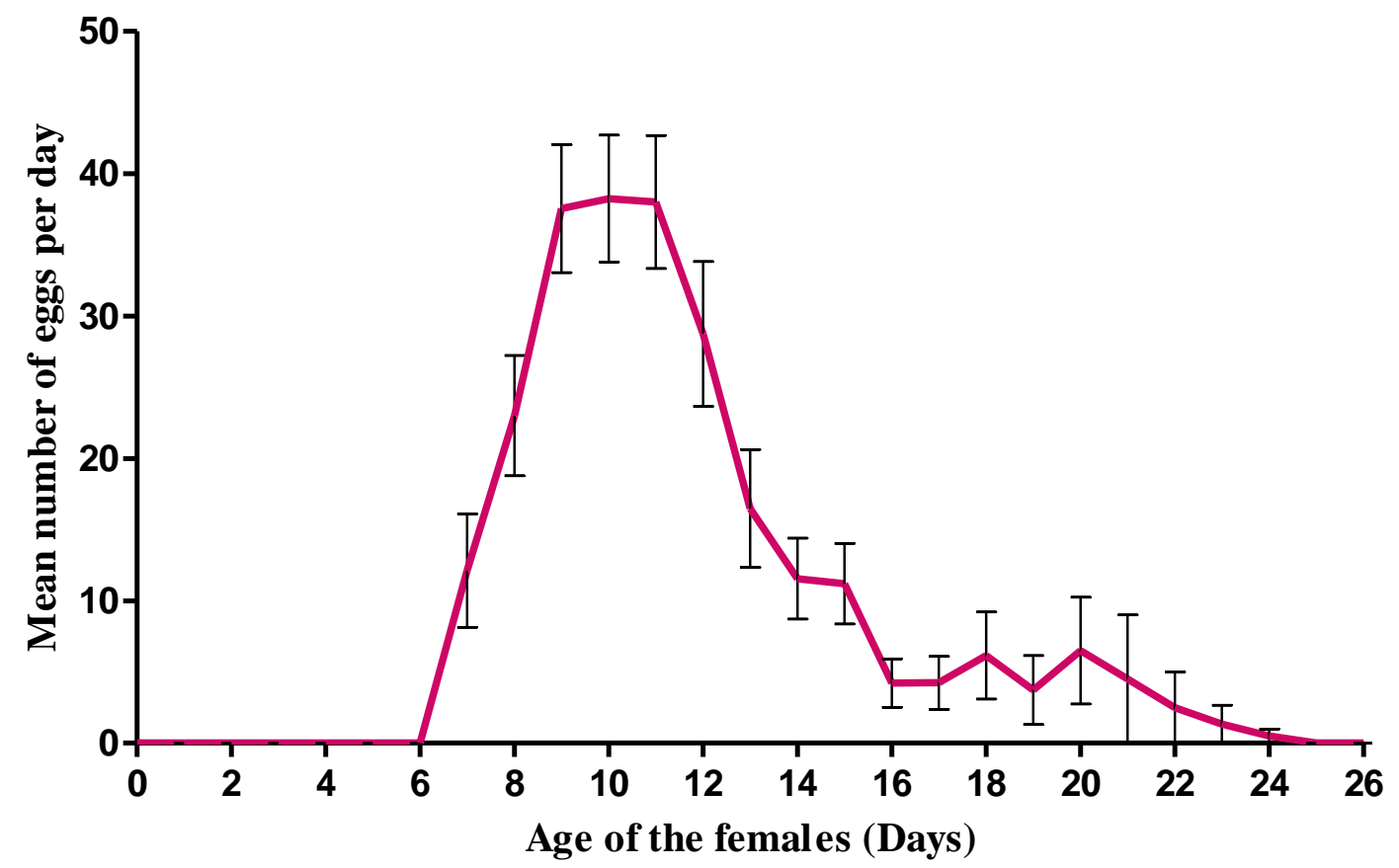

Figure 1. Daily egg-laying capacity of the females of $P$. marginatus at $28 \pm 2{ }^{\circ} \mathrm{C} ; 75 \pm 5 \% \mathrm{HR}$; 12:12h LD

$$
(\mathrm{F}=61.32 ; \mathrm{ddl}=49 ; P<0.0001)
$$

\subsubsection{Survival of P. Marginatus Females}

The average life span of females of $P$. marginatus is $18.44 \pm 3.31$ days. The survival rate of females of $P$. marginatus is highest when the age of the latter is between 1 and 11 days. From day 12 onwards, this rate decreases gradually until day 27 when no females survive (Figure 2). 


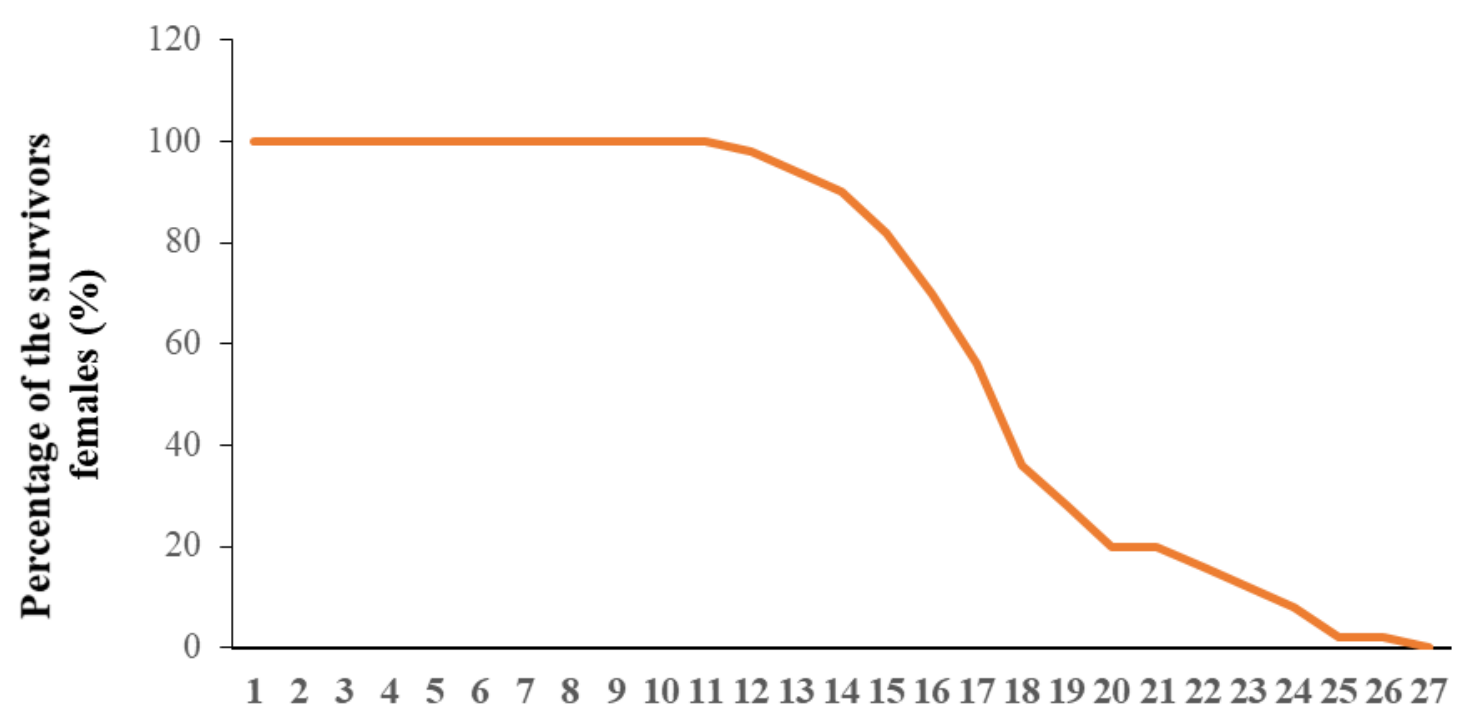

Age of the females (Days)

Figure 2. Percentage of surviving P. marginatus females by age

\section{Discussion}

The average development time of males of $P$. marginatus at $28 \pm 2{ }^{\circ} \mathrm{C}, 75 \pm 5 \% \mathrm{RH}(29.70 \pm$ 5.58 days) is relatively longer than that of females ( $25.98 \pm 4.47$ days). Indeed, males have an additional stage of development (fourth larval stage which represents the nymph) that females do not have. This explains the relatively longer development time of males in comparison to females. These results are consistent with the data of Walker et al. (2003), Amarasekare (2007), Amarasekare et al. (2008), Tanwar et al. (2010), Mani et al. (2012) and Munwar et al. (2016).

In the adult stage, females do not start laying at the same time. They spend a period called pre-oviposition which corresponds to a period of physiological maturity (oocyte formation and maturation). After this period, the oviposition period corresponding to the time between the first and last egg laying occurs. In this study, it extends to the 24th day of emergence of females. But the average laying day is $6.13 \pm 3.02$ days. These results are in agreement with those obtained by Hintenou (2015) where just after laying, females of $P$. marginatus do not die at the same time but spend a time before dying. This post-oviposition period does not exceed 10 days and averages $7.45 \pm 4.27$ days. The longevity of a female P. marginatus is between 13 and 27 days after emergence and averages $18.44 \pm 3.31$ days.

A female P. marginatus laid an average of $25.26 \pm 11.16$ eggs per day for an average of 8.88 \pm 3 days, which corresponds to 224.46 eggs likely to be laid during the lifetime of a female $P$. marginatus. Indeed, Walker et al. (2011) showed that a female P. marginatus usually lays between 100 and 600 eggs over a period of one to two weeks. However, the number of eggs laid daily is not uniform during the laying period. This number fluctuated from the first to the last day of egg laying. This decrease would probably be related on the one hand to the depletion of the oocyte stock in the female's ovary and on the other hand to the ageing of this female. Furthermore, the variability in the number of eggs laid per day per female would 
probably be related to factors intrinsic to each female. This is the very first time that such a result has been obtained on the average daily fertility of $P$. marginatus. Furthermore, the high mortality rate of the early larval stages of $P$. marginatus could be explained by their's relatively high susceptibility to slight variations in the environmental conditions; this may also be due to the movement of the early stages away from leaf tissue and their fall from plants as these stages are highly mobile. Stages intended to give females are more vulnerable than those intended to give males. Indeed, no mortality was noted during the third and fourth larval stages of males unlike the third larval stage of females where a mortality rate of $35.02 \%$ was recorded. This difference would be related to the physiology of both sexes. The male appears progressively by passing through a pupal stage whereas the female is obtained at the end of the deep modifications of the larva of the third stage. These spontaneous changes probably have an impact on the survival of individuals. However, in nature, females are more important than males. This difference is probably related to the longevity of these different individuals. Indeed, males have a very short life span (2.5 days) compared to females (19.6 days) (Munwar et al., 2016).

\section{Conclusion}

Daily egg laying by a female $P$. marginatus is not uniform during the laying period. It decreases with the age of the female. Females of $P$. marginatus have a pre-oviposition, oviposition and post-oviposition periods. During the oviposition period, spawnings peaked on the 10th day after emergence of the females and then began to decrease until the 25th day when there were no more spawnings. Also, during the development of the pest, important mortalities of the second and third larval stages were noted which are linked to the abiotic conditions of its living environment. The average total development time of $P$. marginatus is approximately 29.70 days for males and 25.98 days for females.

\section{Acknowledgments}

We would like to thank IDRC/CORAF-WECARD and IITA for giving the first author this opportunity to conduct his research activities in their institution IITA-Benin within the framework of the CORAF-WECARD/IITA Research Award for Agricultural Research for Development.

\section{References}

Amarasekare, K. G. (2007). Life history of papaya mealybug (Paracoccus marginatus), and the effectiveness of three introduced parasitoids (Acerophagus papayae, Anagyrus loecki, and Pseudleptomastix mexicana). Ph.D. dissertation, University of Florida, 114 p.

Amarasekare, K. G., Mannion, C. M., Osborne, L. S., \& Epsky, N. D. (2008). Life history of Paracoccus marginatus (Hemiptera: Pseudococcidae) on four host plant species under laboratory conditions. Entomological Society of America, 37(3), 630-635. https://doi.org/10.1603/0046-225X(2008)37[630:LHOPMH]2.0.CO;2

Ben-Dov, Y. (2015). Paracoccus marginatus, Williams and Granara de Willink, http//www.Sel.Barc.USDA.Govn/catalog/Pseudoc/Paracoccusmarginatus.Htm (Accessed 
20April 2016).

Cham, D., Davis, H., Obeng-Ofori, D., \& Owusu, E. (2011). Host Range of the Newly Invasive Mealybug Species, Paracocccus Marginatus Williams and Granara De Willink (Hemiptera: Pseudococcidae) in Two Ecological Zones of Ghana. Research in Zoology, 1(1), $1-7$.

Galanihe, L. D., Jayasundera, M. U. P., Vithana, A., Asselaarachch, N., \& Watson, G. W. (2011). Occurrence, distribution and control of papaya mealybug, Paracoccus marginatus (Hemiptera: Pseudococcidae), an invasive alien pest in Sri Lanka. California, USA. Tropical Agricultural Research and Extension, 13(3), 81-86. https://doi.org/10.4038/tare.v13i3.3143

Goergen, G., Ajuonu, O., Kyofa-Boamah, M. E., Umeh, V., Bokonon-Ganta, A. H., Tamò, M., \& Neuenschwander, P. (2014). Classical Biological Control of Papaya Mealybug in West Africa. Biocontrol News and Information, 35(1), 5N-6N.

Goergen, G., Tamò, M., Kyofa-Boamah, M. E., Bokonon-Ganta, A., \& Neuenschwander, P. (2011). Papaya mealybug, Paracoccus marginatus (Hemiptera: Pseudococcidae), a new invading pest in West Africa. Biocontrol News and Information, 32(2), 9N-10N.

Helemul, A. (2013). Mealybug threatens papaya production. The daily star, Published: Wednesday, August $\quad$ 7, 2013. Available https://www.thedailystar.net/news/mealy-bug-threatens-papaya-production (Accessed 22 April 2016)

Heu, R. A., Fukada, M. T., \& Conant, P. (2007). Papaya mealybug, Paracoccus marginatus Williams and Granara de Willink (Hemiptera: Pseudococcidae). State of Hawaii New Pest Advisory No. 04-03, March 2007. Department of Agriculture, Hawaii.

Hintenou, M. V. (2015). Host plant suitability of the papaya mealybug, Paracoccus marginatus Williams and Granara de Willink (Hemiptera: Pseudococcidae), and the host specificity of its natural enemy, Acerophagus papayae noyes (Hymenoptera: Encyrtidae) introduced into africa. Msc. Dissertation. University of Ghana, Legon, 142p.

Kirsur, M. V., Sakthivel, N., Mahimasanthi, A., Balasaraswathi, S., \& Bindroo, B. B. (2014). Weed hosts of Papaya mealybug (Paracoccus marginatus) in mulberry ecosystem of Tamil Nadu. Ind. J. Sericulture, 53, 78-80.

Mani, M., Shivaraju, C., \& Shylesha, A. N. (2012). Paracoccus marginatus, an invasive mealybug of papaya and its biological control -An overview. Journal of Biological Control, 26(3), 201-216.

Meyerdirk, D. E., Muniappan, R., Warkentin, R., Bamba, J., \& Reddy, G. V. P. (2004). Biological control of papaya mealybug, Paracoccus marginatus (Hemiptera: Pseudococcidae) in Guam. Plant Prot. Quart., 19, 110-114.

Miller, D. R., Williams, D. J., \& Hamon, A. B. (1999). Notes on a new mealybug (Hemiptera: Coccoidea: Pseudococcidae) pest in Florida and the Caribbean: The papaya mealybug, Paracoccus marginatus Williams and Granara de Willink. Insecta Mundi, 13(3-4), 179-181. 
Muniappan, R. (2011). Recent invasive hemipterans and their biological control in Asia. Conference paper, 5th meeting of the Asian cotton research \& development Network, https://www.icac.org/tis/regionalnetworks/asian-network/meeting5/documents/papers/PapMu niappanR.pdf (Accessed 22 April 2016).

Muniappan, R. (2014). Papaya Mealybug, Paracoccus marginatus. Powerpoint presentation CRP-IPM Virginia Tech. May 15, 2014.

Muniappan, R., Meyerdirk, D. E., Sengebau, F. M., Berringer, D. D., \& Reddy, G. V. P. (2006). Classical biological control of the papaya mealybug, Paracoccus marginatus (Hemiptera: Pseudococcidae) in the Republic of Palau. Florida Entomology, 89, 212-217. https://doi.org/10.1653/0015-4040(2006)89[212:CBCOTP]2.0.CO;2

Munwar, A., Mastoi, M. I., Gilal, A. A., Shehzad, A., Bhatti, A. R., \& Zia, A. (2016). Effect of different mating exposure timings on the reproductive parameters of papaya mealybug, Paracoccus marginatus (Hemiptera: Pseudococcidae). Pakistan Entomologist, 38(1), 65-69.

Saengyot, S., \& Burikam, I. (2011). Host Plants and Natural Enemies of Papaya Mealybug, Paracoccus marginatus (Hemiptera: Pseudococcidae) in Thailand. Thai Journal of Agricultural Science, 44(3), 197-205.

Sharma, S., Bhatia, S., Sharma, J., Andotra, S., Sudan, M., \& Sharma, K. (2013). First record of Paracoccus marginatus (Hemiptera: Pseudococcidae), an invasive alien species on papaya (Carica papaya L.) in Jammu ( $\mathrm{J}$ and K), India. Munis Entomology and Zoology, 8(2), 664-671.

Suganthy, M., Janaki, I., \& Sakthivel P. (2012). Biology of mealybugs: Paracoccus marginatus (Williams and Granara de Willink) and Phenacoccus solenopsis (Tinsley) on sunflower under greenhouse and laboratory. Madras Agric. J., 99, 371-373.

Tanwar, R. K., Jeyakwnar, P., \& Veonila, S. (2010). Papaya Mealybug and its Management Strategies. Technical Bulletin. 22. National Centre for Integrated Pest Management New Delhi. 22 pp.

Walker, A., Hoy, M., \& Meyerdirk D. (2011). Papaya Mealybug, Paracoccus marginatus Williams and Granara de Willink (Insecta: Hemiptera: Pseudococcidae). University of Florida, EENY-302: 7 pp.

Walker, A., Hoy, M., \& Meyerdirk, D. E. (2006). Papaya Mealybug, Paracoccus marginatus Williams and Granara de Willink (Insecta: Hemiptera: Pseudococcidae). EENY- 302. Featured Creatures. Entomology and Nematology Department, Florida Cooperative Extension Service, Institute of Food and agricultural Sciences, University of Florida, Gainesville, Florida, USA.

Walker, A., Hoy, M., \& Meyerdirk, D. E., 2003. Papaya mealybug, Paracoccus marginatus Williams and Granara de Willink (Insecta: Hemiptera: Pseudococcidae). EENY-302. Featured Creatures. Entomology and Nematology Department, Florida Cooperative Extension Service, Institute of Food and Agricultural Sciences, University of Florida, Gainesville, FL. Available 
from http://if-srvv-edis.ifas.ufl.edu/pdffiles/IN/IN57900.pdf

Williams, D. J., \& Granara de Willink, M. C. (1992). Mealybugs of Central and South America. London: $C A B$ International. 635 p.

\section{Copyright Disclaimer}

Copyright for this article is retained by the author(s), with first publication rights granted to the journal.

This is an open-access article distributed under the terms and conditions of the Creative Commons Attribution license (http://creativecommons.org/licenses/by/4.0/). 